

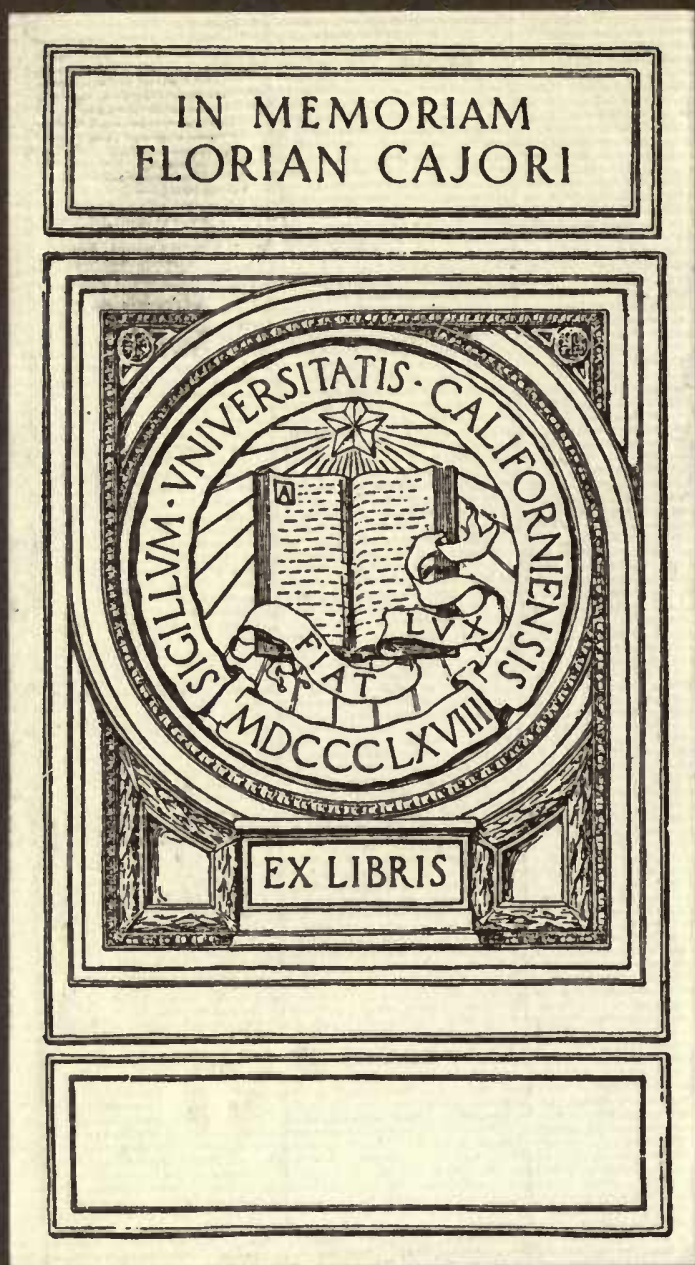




\section{CATALOGUE OF A}

Loan Exhibition of

Early Scientific Instruments

in Oxford

Opened by Sir William Osler after his Presidential

Address to the Classical Association

on 16 May, I919

Printed for the President of the Classical Association

By Frederick Hall, at the Clarendon Press, Oxford

I9I 9 


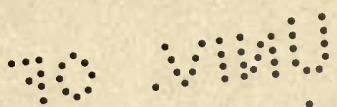

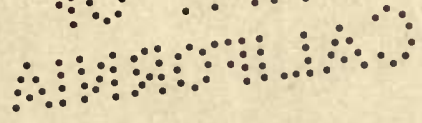

CAJORI 


\title{
CATALOGE
}

\author{
OF A
}

\section{LOAN EXHIBITION OF EARLY SCIENTIFIC INSTRUMENTS IN OXFORD}

\section{MATHEMATICAL INSTRUMENTS}

1. Alabaster column, 22 inches high, with geometric solids and columns representing the five orders of Architecture. Probably i7th cent.

Picture Gallery, Bodleian Library.

2. Geometric Solid in boxwood.

? 1780 .

Apparently of the period of Hornsby.

University Observatory.

3. A set of 'Sollid Bodys'. Boxwood.

Orrery Coll., 43 .

The set includes-3 tetrahedrons, to cubes of various sizes, $3 \mathrm{bi}$ sected cubes, 5 quarters and I eighth of a cube, 2 octahedrons, 2 dodecahedrons, 2 icosahedrons, 2 conic sections, and I dissected scalene prism.

4. Two 4-inch Spheres, bisected on the ecliptic. Beechwood.

Saville Room, Bodleian Library.

These two small wooden spheres are all that remains of the elaborate instrumental outfit of the Savilian Professors which was kept in the Cista Mathematica. The inventory was printed in the 1697 catalogue of the Bodleian Library.

The Sphere was an essential adjunct in education in Europe from the days of Gerbert onward.

'When Prince Henry was receiving instruction in mathematics from Edmund Wright, the latter for the more easy information of the Prince contrived a sphere of wood, about three quarters of a yard in diameter, which 
lay neglected and out of order in the Tower, at London, and Sir Jonas Moore begd it of this present majestie, who showed it to me.'-Aubrey's Lives.

5. Three Spineres. Boxwood. Diameter $3 \frac{x}{4}$ inches.
Orrery Coll. 5 .

Marked in ink to illustrate propositions on spherical triangles. Two of the spheres are supported in turned wooden pedestal cups.

6. Abacus.

Size about $I_{4}$ inches $\times 4 \frac{1}{2}$ inches.

? Rawlinson Bequest. Charter Case, Drawer 38. Bodleian Library.

7. Napier's Bones.

c. 1730 .

In boxwood case, $3 \frac{1}{2}$ inches $\times 2 \frac{5}{8}$ inches.

Ashmolean Museum.

For multiplication and division on the system invented by John Napier of Merchiston (1550-16r7).

\section{DRAWING INSTRUMENTS.}

'The Making of good Mathematical Instruments is almost peculiar to the English' (Stone, I758).

8. Set of Drawing Instruments.

In flat case. By Rowley.

Orrery Coll. (34).

Silver with chased decorations. The set includes a pair of $6 \frac{1}{2}$-inch compasses, with pen, pencil-holder, and dotting wheel ; 5 -inch dividers ; ruling pen; turnscrew; and a long ruling pen that may belong to a different set.

9. 13.inch Compasses.

Wood and iron (broken).

10. Proportional Compasses.

Silver with steel points.

Inscr. : John Rowley Londini Fecit.

Oriel College.

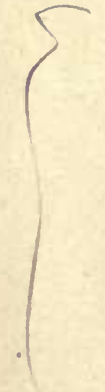

11. Four-sided Scale with Compasses in one end and a Pencil-holder in the other.

Silver, 6 inches in length. In original case. Orrery Coll. (2I). Inscr.: I. Rowley Fecit.

Orrery Coll. (20).

12. Parallel Rulers.

Ebony, 7 inches long.

Cf. Stone's Bion, Pl. X, Fig. R.

Orrery Coll. (46a).

\section{Protractors.}

13. Rectangular Protractor.

Ivory, 6 inches.

Inscr.: I. Rowley Fecit.

Orrery Coll. (46b).

With a scale of $\frac{1}{24}$ th of an inch along one edge. 
14. Recipient Angle or Semicircular Protractor.

Radius 4 inches.

Orrery Coll. (49?).

Inscr.: I Rowley fecit.

Semicircle graduated $0^{\circ}-180^{\circ}$ in both directions. Fitted with adjustable rulers, marked Ext. and Int ${ }^{r}$., as in Stone's Bion, Pl. XI, Fig. D. This type of instrument was of great use for plotting fortifications.

\section{Circular Protractor.}

Diameter $12 \frac{3}{4}$ inches.

Inscr. : J. Sisson, London.

Divided to $\frac{1}{2}$ degrees. A very beautifully graduated instrument.

16. 9 -inch Sector.

Ivory, with silver hinge.

Orrery Coll.

Inscr. I Rowley fecit.

17. 6-inch Sector.

Ivory, with brass hinge.

Apparently by Rowley, but unmarked.

18. I2-inch Sector.

Brass, in deal box.

19. 9-inch Sliding Gunter.

Ivory.

Inscr.: I: Rowley, fec.

20. Io-inch Artillerist's Gunnery Scale.

Ivory, with silver slider.

Inscr. : I Rowley Fecit.

Slide Rule.

21. Oughtred's Circles of Proportion and Horizontal Instrument.

I632.

Diameter I foot 6 inches.

St. John's College.

This fine instrument is inscribed with the name of the maker, Elias Allen fecit, and with the name of the donor-

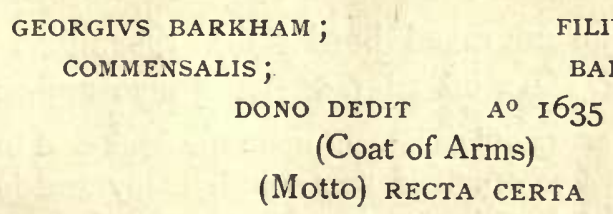

(Coat of Arms)

(Motto) RECTA CERTA

Unfortunately all the movable parts but the base-plate and a couple of thumb-screws are missing.

The face of the instrument is engraved with Oughtred's Horizontal Instrument. The back is engraved with eleven Circles of Proportion 
as described in Arthur Haughton's book, a copy of which was presented to St. John's College by George Barkham, to explain the use of the instrument.

This instrument is probably the oldest Slide Rule now in existence. E. Gunter of Christ Church invented the straight logarithmic scale in I620. Oughtred made the first logarithmic slide rule in 1630 , and his Circles of Proportion or circular Gunter scales in $163^{2}$.

22. Gunter's Chain.

Standard Measure.

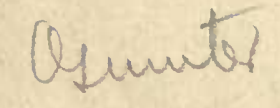

Gunter's Chain contains in length 4 poles or $66 \mathrm{feet}$, and is divided into Ioo links ; each link is, therefore, in length $7 \frac{92}{100}$ inches.

\section{PORTABLE SUNDIALS}

\section{Chinese Sundial and Compass.}

Presented by W. Lloyd.

Pitt-Rivers.

24. Pocket Dial, Almanack, Compass and Tidetables.

1554 .

Maker's initials, V. C.

Bodleian Library.

A most elaborate instrument and book of tables in gilt brass, with a ring for suspension. Both front and back are embellished with engraved ornament. ${ }^{1}$

Front. In a square frame an ovoid boss with a coat of arms [ ], three bars [ ], in chief [ ] as many roundels [ ]. Crest, a buck on an esquire's helmet. Above in a pediment, two cherub heads on a globe and two quadrants.

Back. Motto in oval + Aske+me+

$$
\begin{gathered}
+ \text { not }+ \text { for }+ \text { ye }+ \\
+ \text { Gett }+ \text { me }+ \text { not }+ \\
+\mathrm{R}+\mathrm{P}+
\end{gathered}
$$

Under a pediment above, an astrolabe. One of the two cherub heads is used as a catch.

Round the edge is an engraved border that resembles the work upon the book-dial (Brit. Mus. 88. I2-I. 294) and also appears on the

1 The elegant style of engraved ornament upon the back and front of this instrument was much in vogue, both in western Germany and in Holland, during the second half of the 16th century-witness the decorative frames enclosing the titles of Eden's Arte of Navigation, 156I, or of the charts of I. Wagenaer collected in Auregain, Speculum nauticum, 1583 , and again in the more finely executed plates by Theodore de Brij in A. Ashley's The Mariners Mirror, 1588. 
work of V.S. (=Ulrichus Schmid) in the Miller collection at the S. Kensington Museum.

Ivory Portaria made at Nuremberg in the 16 th and 17 th centuries closely resemble the small portable tablet dials of the Chinese.

25. Tablet Dial and Compass and Wind Vane.

I6I4.

Engraved Ivory, coloured.

Size $3^{\frac{1}{2}}$ inches $\times 2 \frac{1}{4}$ inches. Lienhart Miller, $\mathrm{I}_{6} \mathrm{r}_{4}$.

Presented by Greville J. Chester, I865-7, to the Ashmolean Museum.

26. Tablet Dial and Compass.

Size $1 \frac{7}{8}$ inches $\times 1 \frac{1}{4}$ inches. c. 1620.

Ashmolean Museum.

A much smaller instrument of the same kind with three dials only, viz. horizontal and vertical dials with the same string gnomon and a horizontal dial to show the Italian hours.

\section{Sundial and Compass.}

c. 1750.

Brass, octagonal. Diameter 2 inches. No. 1913.916, Ashmolean Museum. Johan Schretteger in Augsburg.

The hour ring and pin gnomon are adjustable. There is a quadrant for setting the hour ring for the latitude. This and the gnomon fold flat over the face of the compass.

28. Sundial and Compass.

Gilt Brass, octagonal. Diameter 3 inches.

With adjustable hour ring like the last but with small, folding plumet in addition.

The following latitudes are inscribed underneath the compass box : Elev. Poli. Lisbon 39, Rom 42, Venedig 45, Wien. Augsp. 48, Nürnb 49, Prag 5o, Warschau 52, Lübeck 53, Hambu 54, Riga 56, Moscau 57, Petersbu, Stockholm 6o.

29. Oughtred's Double Horizontal Dial.

By E. Allen.

$163^{2}$.
St. John's College.

The 'Horizontall Instrument' is engraved on the face of the plate bearing the Circles of Proportion exhibited in the Mathematical Series.

\section{Dialling Sphere.}

Diameter $10 \frac{3}{8}$ inches; height 14 inches.

I. Rowley fec.

c. 1700.

Orrery Coll. 3 .

With a contemporary manuscript describing its use.

\section{CHILINDRES OR PILLAR DIALS}

The Chilindre or Pillar Dial has been derived from an ingeniously contrived dial of which the origin is to be sought among the Mediter-
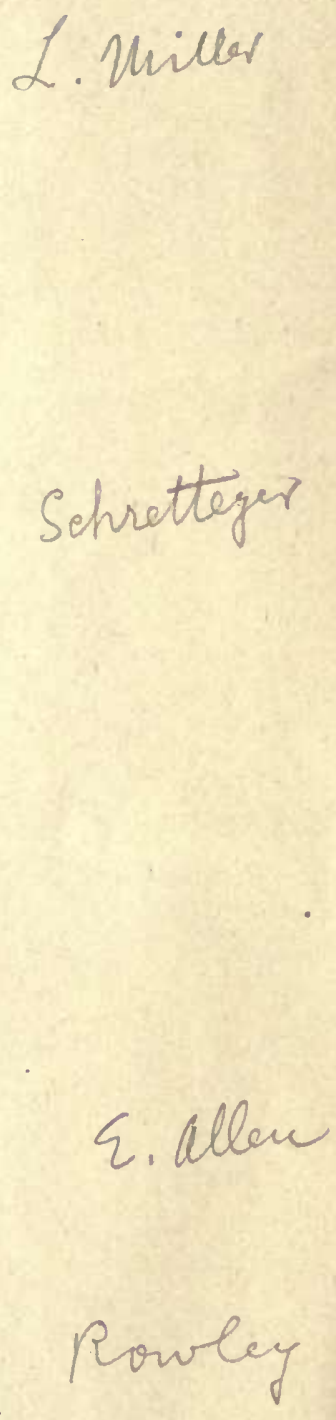
ranean peoples. One of the earliest treatises upon it by an Englishman is the Practica chilindri, written by John Hoveden, Chaplain to Queen Eleanor the mother of King Edward.

The editor and translator of the treatise, Edmund Brock, makes out that the particular chilindre described was made for latitude $51^{\circ} 5^{6}$, which was probably intended for the latitude of Oxford. This surmise is supported by another Bodleian MS. entitled 'Composicio chilindri cum ejus operacione que facta est apud Oxoniam'-MS. Digby 98from which we gather that there must have been competent dial makers in the City at that early date.

31. 'Column', 'pillar', or 'Shepherd's dial'.

I7th cent.

O. C. XXX Ashmolean Museum.

The dial forms part of the bone handle of Absalom Leech's Walking Stick and measuring rod.

A hinged gnomon (now missing) is brought over the proper month as indicated by the vertical lines. The stick, held upright, is then turned until the shadow of the gnomon falls vertically on the column. The position of the point of the shadow with reference to the oblique hour lines will then indicate the time.

32. Column Dials.

Igth cent. Pitt-Rivers.

Until recently such column dials were in common use in the Pyrenees.

\section{ARMILLARY SPHERE}

\section{Ptolemaick Armillary Sphere.}

Bronze. 2 feet in diameter.

c. 1595 .

Bodleian Library.

Supported by three lions sitting on a triangular base, engraved with the coat of arms and quarterings, crest, and badge of Henry, ninth Earl of Northumberland ( $1564-1632)$.

According to the Benefactor's Book it was presented to the Bodleian Library by Sir Josias Bodley in I6oI, with four other instruments, three of which have disappeared.

\section{UNIVERSAL ASTRONOMICAL RING DIALS}

\section{Universal Astronomical Ring Dial.}

Brass.

Pitt-Rivers.

35. Universal Astronomical Ring. Dial.

Diameter 3 inches. Silver.

By Butterfield, Paris. 


\section{RING DIALS}

36. Corean Sun Clock.

A wooden ring dial.

Modern.

Pitt-Rivers.

37. English Ring Dial.

Diameter $I_{2}^{\frac{1}{2}}$ inch.

c. 1680 .

[5829. 1886] Ashmolean Museum.

38. Ring Dial.

I7th cent.

Diameter $I \frac{1}{2}$ inch.

Found on Greenham Common near Newbury.

$$
\begin{aligned}
& \text { I shew } y^{e} \text { time } \\
& \text { if } y^{e} \text { Sun shine }
\end{aligned}
$$

Other specimens exhibited belong to the Pitt-Rivers Collection.

\section{QUADRANTS}

39: Sacrobosco's Quadrant.

Figure copied by Delambre, fig. 54, from the I4th cent. MS. Bibl. nat. Paris lat. 7 196, ff. $25^{-2} 7^{\text {b }}$.

'Tractatus magistri Io. de Sacrobosco super compositione quadrantis simplicis et compositi et utilitatibus utriusque et.' Beg.: 'Omnis scientia per instrumentum operativa.' Ends: 'et hec michi dicta de simplici et composito quadrante sufficiant.'

\section{John of Montpellier's Old Quadrant.}

Radius $5 \frac{7}{8}$ inches.

f. 72 , MS. Ashmole I522.

An excellent figure drawn before $135^{\circ}$.

\section{John of Montpellier's Old Quadrant.}

Radius $4 \frac{3}{4}$ inches.

f. I 7 , MS. Bodl. 472 (S. C. 2492).

A roughly executed figure by Tristrandus of Louvain, $\mathbf{I} 437$.

42. New Quadrant of Profacius.

1301.

MS. Ashmole I522 (temp. Edw. II), ff. I22-I32. MS. Digby I 7 ( 15 th cent.), ff. 160,164 .

Bodleian Library.

43. Quadrant.

Bronze. Radius I foot. c. I3oI-I350.

Merton College. of the astronomical instruments belonging to Merton College, and this is confirmed by the coincidence of the first point of Aries with the I $3^{\text {th }}$ of March in a circular scale on the back of the instrument.

44. Sinecal Quadrant.

Date of figure c. r $400 .^{2}$

S. C. 2142. MS. Bodley 68, f. 48 .

45. The Quadrant of Robert Recorde.

I596.

Figured in The Castle of Knowledge, p. 52. 
46. Quadrant.

1658.

Paper on wood. Radius II inches.

Orrery Coll. (37).

Henricus Sutton Londini fecit.

47. Quadrant.

1669.

Brass. Radius $4 \frac{3}{8}$ inches.

Hen: Sutton fecit.

This quadrant is fully described with an engraving of one dated 1658, but otherwise similar, by John Collins, 'Accountant Philomath', in his 'Sector on a Quadrant' of great use to Seamen and Practitioners in the Mathematiks, 1659 .

Books, too, were not unfrequently illustrated with copper plate engravings of quadrants, which unscrupulous persons used to cut out and mount for use as instruments. In the Christ Church Library there is a case in point. In a copy of M. Dary, Dary's Diarie or the Description and Use of a Quadrant, 1649, there was such an illustration. There is also a marginal note by a former owner of the book:

'I have Taken away ye Quadrant or rather I should say ye whole Figure which heere was inserted; and Pasted it on a Boarde.' G.F.

It was a Sutton's Quadrant.

48. Gunter's Quadrant.

Radius $4 \frac{1}{2}$ inches. Brass : with lateral sights.

Inscribed I.W. 1665. (John Worgan) No. 45 A. 1892.

Constructed for about latitude $5 \mathrm{I}^{\circ} 4 \mathrm{O}^{\prime}$. On the face is a quadrant with divisions numbered I-IO-I including a table calendar LY = (leap years) (I6)6o to (I6)84. D(ominical) L(etters) and Ep(acts).

\section{Gunter's Quadrant.}

Ivory. Radius $4 \frac{1}{4}$ inches.

I. Rowley fecit.

On stand, with three levelling screws, double sights, pin-hole, and cross thread.

\section{Gunter's Quadrant.}

Boxwood. Radius $3 \frac{3}{4}$ inches.

Gunther Coll.

51. Io in. Quadrant with Sights.

c. 1728 .

The property of Sir William Osler.

J. M. Kleman Fecit Amsterdam.

Sights with slits with threads and pin-holes.

Hour circle with marked I-XII, I-XII. Zodiac circle. Month circle. Two revolving hands or indices. 'Middach Middenacht.'

A small printed booklet shows that this instrument and tables were specially intended for the use of Herman Boerhaave at his country 
house at Oud-Poelgeest, at $52^{\circ} 12^{\prime} \mathrm{N}$. latitude. The book was printed at Leyden in 1728 and the tables were prepared by the famous Nic. Cruquius. There is great appropriateness in this instrument having fallen into the hands of the one man who is best qualified to value Boerhaave's work.

A similar instrument has been figured by Lansberg in 1663 .

52. Quadrant adapted for use as a Sun-clock.

Ch. Ch. O.P. 2.13.

From La Siljan, Dalecarlia.

Pitt-Rivers Coll.

\section{ASTROLABES}

Three instruments in the Oxford collections represent the astrolabe in its eastern form. Two of them have a special interest for their personal associations; the one with Archbishop Laud, the other with John Selden, the latter having been the first to point out the source of Chaucer's thorough knowledge of the astrolabe. These oriental instruments indicate the type from which the Western and English astrolabes were copied and evolved. Indeed, the earlier western instruments differ from their Arabian prototypes in little save the lettering being in western instead of Arabic script. A comparison of the fine astrolabe of r208, described by Sarrus, with the Laudian instrument, with one of the Merton instruments, and with others in the unrivalled collection of $\mathrm{Mr}$. Lewis Evans shows how little the construction of the instrument has changed in the course of years. ${ }^{1}$

It was from the East that the astrolabe received the decorative quality which it never lost; even after being reproduced for centuries by European craftsmen. It has always been the most artistic of common scientific instruments.

\section{Arabian Astrolabe.}

Type of 1224.

Diameter $7 \frac{3}{4}$ inches.

With eight tablets; one made for the latitude of Morocco. Bodleian Library, MS. Selden Superius, 72. I, S.C. $3^{205}$.

This beautifully finished instrument came to the University with the Library of John Selden in 1659.

54. Arabian Astrolabe.

Diameter $6 \frac{3}{8}$ inches.

Presented by Archbishop Laud, whose arms impaling Canterbury are engraved on the back of the bracket.

55. Astrolabe (or Saphea) and Quadrant.

Diameter $13 \frac{4}{10}$ inches.

c. 1340, before 1350 .

This instrument, and the 1350 Astrolabe in Merton College, belong 1 See also p. 24. 
to a very rare type of which, so far as we know, there are no other English examples out of Oxford and which may have been constructed for some member of the early School of Astronomy at Merton College. The chief peculiarity of the type consists in the absence of changeable tablets and of a raised rim round the base plate to contain tablets and rete. They are astrolabes without a mother, and they are combined with quadrants of large size. They resemble the saphea of William Anglicus, I23r.

The bracket for suspension is missing; it has evidently been torn away from the notch at the upper side of the thin disc.

56. Astrolabe or Saphea, Plumb Level and Quadrant. c. 1350.

Diameter $14 \frac{1}{4}$ inches.

Merton College.

Brass ; engraved, 'Lat. $5^{2 .} 6^{\mathrm{m}}$ Oxonia.'

57. Astrolabe.

Diameter $9 \frac{3}{4}$ inches.

c. 1390.

Merton College.

58. Astrolabe.

1527.

Bronze. Diameter $6 \frac{3}{8}$ inches.

St. John's College.

Inscribed on the back with the name of the maker:

GEORGIVS HARTMAN

NORENBERGE FECIT.

ANNO MD XXVII

This with other mathematical instruments was given in 1634 to St. John's College by Archbishop Laud, whose arms are engraved upon the back. The bracket is artistically chased with scrolls and two roses, a design which may be seen upon other examples of Hartman's work e. g. on his 1537 astrolabe in the British Museum and on Mr. Lewis Evans's No. 2024 which is stamped GEORGIVS HARTMAN NORENBERGE FACIEBAT ANNO MDXXXXII, and another stamped GEORGIVS HARTMAN NORENBERGAE FACIEBAT ANNO MDXLVIII is in the South Kensington Museum. The adoption of 'Tudor' roses as part of the design has been suggested to indicate that these Hartman astrolabes 'were made for English use, possibly for presentation to some royal personage, or for use in the British Navy' (Ionides). But the same design is also characteristic of the contemporary work of Johannes Wagner, also of Nuremberg, and, as Mr. Lewis Evans has suggested, was probably copied from an Italian original, of which he has an example in his collection.

The shackle which is connected with the swivel and ring is also ornamented, and even the shackle-pin is kept in place by a washer designed as a 4-pointed flower.

Hartman's graduations and finish were finer and more accurate than those of the instruments of his predecessors. 
59. Astrolabe with Plates for Solar and Lunar Calculations. 1537. Diameter $8 \frac{7}{8}$ inches.

St. John's College.

Inscribed + RODES * BRECHTE I537. Engraved with two shields, one bearing a three-flowered 'thistle, the other a Merchant's mark. Grafiti :- ' $T$ N' and the name 'Pointer' faintly scratched.

Bequeathed in c. 1754 by John Pointer to St. John's College.

\section{INSTRUMENTS OF THE FOURTEENTH CENTURY \\ Illustrations of}

60. Albion.

Invented by Richard of Wallingford, of Merton College, Bishop of St. Albans.

61. Rectangulus of Richard of Wallingford.

62. Navicula de Venetiis.

63. Equatorium of Profacius, or Semissis.

64. Turket.

c. 1320.

Digby 168, f. 61 .

Digby 98, f. $75-7$.

Temp. Edw. II.

Ashmolean I522.

Temp. Edw. II. Ashmolean 1522, f. I77.

\section{VOLVELLES}

Sun and Moon Volvelles were handy circular scales, by means of which calendrical calculations could be readily performed. The earliest that we have seen dates from before the middle of the $4_{4}$ th cent., and they appear to have remained in use for some time after the advent of printed books.

A description of their use is found in The Rewle of the Volvelle, MS. Ashm. I9I. In a complete instrument there may be as many as seven circles.

The first and outer circle contains the division of the twenty-four hours and also quarters of hours; the second contains the twelve months; the third the twelve signs of the zodiac, with divisions of degrees; the fourth the times, the rising of the sun and moon; the fifth the meridian altitude with degrees; the sixth the age of the moon; the seventh and last shows the aspects of the sun and moon.

65. Volvelle or Circular Scales for Lunar and Solar Calculations. Quadrant and Zodiac Man.

Diameter $6 \frac{1}{8}$ inches. c. $1400-50$. Merton College.

A composite instrument built upon a circular disc with a small triperforate bracket for suspension. The circumference is drilled with 
seventy-two perforations, perhaps for reading or setting the pointers in the dusk. The circles are now held together by a copper rivet, which may have replaced a tubular pin. If so the instrument would have been a nocturnal, or instrumentum siderale. ${ }^{1}$ The incised lines and figures upon the instrument are of two periods : the older being filled with red colour, the later additions with black. Graffito, C.

66-8. Volvelles.

MS. Ashmolean, 1522, f. 87 , before $135^{\circ}$.

MS. Ashmolean, 210 , c. 1386.

69. Volvellae solis et lunae.

MS. Bodleian, 68 (S. C. 2142), c. 1390.

70. Volvelle.

f. 31, MS. Digby, 167 .

Parchment in perfect order. Diameter $5^{\frac{1}{2}}$ inches.

MS. Ashmolean, 370, f. 25.

71. Volvelle.

c. 1440 .

72. Volvelle (unfinished).

MS. Ashmolean, I9I, ff. 53 ${ }^{\mathrm{b}}$, 199, 2 II.

73. Volvelle.

Parchment. Diameter 5 inches.

Perfect. Coloured, red, blue, and gold.

On the same page as a Zodiac man.

74. Volvelle.

Edw. IV.

MS. Ashmolean, 369 , f. $\mathrm{I}^{\mathrm{b}}$.

I4-.

MS. Ashmolean, 789 , f. $3^{6} 3$.

75. Volvelle.

MS. Ashmolean, I 448 , f. 278.

Coloured parchment. Diameter 6 inches.

1460-62.

The two pointers are marked volvella lune and volvella solis. The rule is written on the upper moveable circle in a spiral direction from the edge to the centre; beg. Pone volvellam solis.

76. Volvellae lune et solis.

I5th cent.

Diameter $4 \frac{3}{4}$ inches.

MS. Digby, 48, f. 203 .

77. Volvelle.

15 -

MS. Ashmolean, $\mathrm{I}_{4} 83$, f. $77^{\mathrm{b}}$.

Constructed to illustrate a work by Raymond Lully.

Planetary Volvelles.

Volvelles designed to illustrate the motions of the Planets are occasionally found in astronomical treatises. An example of such a plane-

${ }^{1}$ Cf. Gemma Frisius, Cosmogr., fol. 50, ed. 1545. 
tarium, $3 \frac{1}{2}$ inches in diameter, the period of about $1433-60$, is in MS. Digby 48, f. II3:

Peter Apian ${ }^{1}$ made such a model on a larger scale, by which he represented the epicyclical motions of the planets by means of movable circles of cardboard of various colours, and expected by such means to be able to find their positions without computation. This model interested the Landgrave Wilhelm IV of Hesse so greatly that he had circles of copper made for the same purpose. He found considerable errors in existing star catalogues, and became convinced of the necessity of making systematic observations. With Tycho he redetermined the position of Spica virginis.

Something of the same kind may be seen in the wonderful instrument book, MS. Savile 100, which is, so far. as we know, as yet undescribed.

The splendid folio work of I. P. Gallucius, Speculum uranicum, I593, is illustrated with very numerous volvelle, one for each of the planets.

\section{ASTRONOMICAL MODELS}

78. Globe. Gilt brass on Stand.

Diameter $5 \frac{1}{4}$ inches.

c. 1700 .

I. Rowley fecit.

79. $2 \frac{1}{2}$-inch Globe set to turn in a brass meridian divided in degrees.

c. 1700.

Orrery Coll. 24 .

80. $1 \frac{1}{2}$-inch Globe of Ivory on a Stand.

c. 1700.

Orrery Coll. 25 .

81. A pair of wire Planetaria.

c. 1700 .

Diameter $15 \frac{3}{4}$ inches.

Orrery Coll. I.

I. Ptolemaic Planetarium.

2. Copernican Planetarium.

82. A pair of Planetaria mounted within Armillary Spheres.

Diameter $\mathrm{I}_{4}$ inches.

c. 1700 .

On Stands, Brass: Scales silvered.

Orrery Coll. 7 .

I. Ptolemaic.

John Rowley Londini fecit.

2. Copernican.

I. Rowley fecit.

${ }^{1}$ Peter Apian's Astronomicum Caesareum 1540, a large book dedicated to Charles V. 


\section{Miniature Copernican Planetarium within an Armillary Sphere. \\ Silver. \\ Orrery Coll. II.}

I. Rowley fecit.

This exquisitely finished working model of the second of Rowley's Planetaria, above mentioned, is probably one of the finest small astronomical models ever made in England. It is supported on an ebony base by a tripod, between the legs of which is a magnetic compass for orientation. This 'very childish toy', as Herschell would have called it, is enclosed in a turned brass-bound casket of lignum vitae.

84. Orrery.

1731.

Circle 3 feet in diameter, I foot high.

Christ Church.

Made by Tно. Wright (Mathematical Instrum ${ }^{t}$

Maker to $H$ is Majesty George $\mathrm{y}^{\mathrm{e}} \mathrm{II}^{\mathrm{d}}$ ) in

Fleet strect LONDON.

85. Orrery.

c. 1750.

Queen's College.

Made by B. Cole and Son

at the

ORRERY

Fleet St.

London:

86. Nocturnal.

18th cent.

University Observatory.

Boxwood, marked with rose and fleur de lys stamps. The rose stamps are identical with those put by Joseph Stutchbury upon his Excise slide-rules, and may also be seen upon an Edm. Culpeper Backstaff in the Pitt-Rivers Collection.

87. Nocturnal.

I8th cent.

Radcliffe Observatory.

Boxwood. A very similar instrument-of the type described by Sir Jonas Moore, A New System of Mathematics, I68I.

The Nocturnal can be traced back to the Instrumentum Syderale described in the Pet. Apiani Cosmographia, per Gemmam Phrysium apud Louanienses, 1539. And even in the preceding century we find figures of instruments that would serve the purpose as, for instance, a figure in MS. Digby 48 , perhaps of the date $1433-62$. 


\section{NON-ACHROMATIC TELESCOPES}

88. $\frac{1}{2}$-inch Ivory mounted I-draw Galilean or Perspective Glass. Orrery Coll. 26.

Outer body ornamented with gold tooling, 4 inches long when closed, $4 \frac{1}{2}$ inches when extended. Draw-tube covered with green vellum. Object glass, $4 \frac{1}{2}$ inches focus, and eyepiece are mounted in ivory cells with screw caps.

We place this example of the 'least kind of Perspective Glasses' first because it represents the telescope with the concave eye lens, the invention of Galileo in 1609 , so famous for the great discoveries he immediately made with it and now so familiar in the form of the common opera-glass. Galileo's best telescope is said to have been 3 feet long. Within a century of its invention Galilean telescopes were being made in considerable numbers in Paris.

\section{PERSPECTIVE GLASSES}

In the eighteenth century the tubes of Perspective glasses were of several sorts and made of various materials. Some are made of stiff paper glued together, covered with parchment or shagreen or leather ; some consist of single tubes, made of light dry wood ; others of several lesser tubes, sliding one within another. The glasses are fixed in the tubes in wooden cells, so as to be easily taken out and put in again, by means of screws, in order that dust or moisture may be readily wiped off from them. At the end of every one of the inward tubes is fitted a wooden ring (=diaphragm) to hinder the lateral spurious rays from coming to the eye, which is found by experience to be more use than could be thought; these rings are generally furnished with female screws in those places whereat the glasses are seated. The Perspectives of 3 or 4 feet, which have but one wooden tube, are most handy, especially, if at each end, instead of covers that screw and unscrew, they have thin sliding pieces of brass for such. ${ }^{1}$

In England Kepler telescopes were made for or by Sir Paul Neile and Messrs. Reeves and Cox. During the latter end of the 17 th century Wm. Ball of Mamhead, Devonshire, using an instrument of $3^{8}$ feet focus observed the double nature of Saturn's ring.

But telescopes of extreme focal length did not find favour in England. Our Savilian Professor Carswell informed Uffenbach in Oct. I 7 Io that "when Halley was with the famous Hevelius, he discovered that they could not see or observe anything with his telescope of ${ }^{1}$ Stone's $175^{8}$ supplement to Bion. Math. Instr., p. 283. 
300 feet, and that his other telescopes were useless, because on account of their length, the centres of the lenses cannot be brought into a straight line. He asserted also that lenses of over great size were of no use, and that neither Newton or Marshall here in England could produce anything of value in this kind.'?

In $1690 \mathrm{John}$ Marshall was practising as a manufacturing optician in the Strand with such success that in January $18,1693^{-4}$, his methods and results received the official approval of the Royal Society. The original letter that he received, signed by 'Edm. Halley, has been facsimiled in the illustrated edition of Green's History of England, p. 1575 .

One certainly, and perhaps two, of the oldest known specimens of his art are in the Orrery Collection at Christ Church. Their many draw-tubes covered with vellum are surprisingly light and smooth in use.

For an early illustration of a telescope with a paper or cardboard tube cf. Zahn, Oculus artificialis, 1685, p. 188. The Orrery instruments by Marshall and Wilson appear to be constructed in accordance with the principles set out at length by Zahn.

\section{TELESCOPES}

89. $\frac{7}{8}$-inch Refractor.

c. 1700 .

Vellum tube, closing to $25^{\frac{1}{2}}$ inches.

Marked IOHN MARSHALL, LVDGATE STREET, LONDON.

The outer body (diam. $3^{\frac{1}{4}}$ inch.) is covered with vellum, blotched green and red and ornamented with book-binding designs stamped in gold. The draw-tubes, of which there are 9, are of cardboard covered with white vellum, and are marked with pencilled rings to indicate full extension. When fully extended it measures 9 feet. The objective is $I_{2}^{\frac{1}{2}}$ inches in diam. with an effective aperture of $\frac{7}{8}$ inch and a focal length of 8 feet. The eyepiece consists of a biconvex lens of 3 -inch focus, which is mounted far within the eyecap. Both object and eye lenses are mounted in turned lignum vitae mounts, provided with wooden screw caps to protect the glasses from dust and injury when not in use.

\section{2-inch Refractor.}

c. I700.

Vellum tube, closing to 30 inches. Orrery Coll. I4.

The outer body is covered with white vellum ornamented with bookbinders' stamps tooled in gold. The 9 draw-tubes extend to I2 feet, but the instrument has no object-glass. Judging from the diameter of

1 Uffenbach, October 6, I7ro. 
the draw-tubes, $4 \frac{1}{2}$ inches at the eyepiece end and 3 inches at the objectglass end, the objective would not have been more than 2 inches in diameter.

The fine and imposing looking eyepiece is, however, complete. It consists of two lenses of 3 inches diam. and 12 inches focal length, and $I \frac{1}{2}$ inches diam., $2 \frac{3}{4}$ inches focal length, mounted about $7 \frac{1}{2}$ inches apart in an eyepiece with a draw-tube.

These Orrery telescopes are of great historic interest as representing the instruments of the time of Flamsteed, who, when he went to Greenwich in 1676 , only had two telescopes, one of 15 and the other of 7 feet focus, a Townley micrometer, and a small quadrant. None of these instruments are now in existence. Halley found no instrument at Greenwich in I7I9. His first acquisition was a 5 -foot Hook telescope.

\section{1. $\frac{1}{2}$-inch Silver Terrestrial Telescope.}

c. 1700 .

One draw : length opens $10 \frac{1}{2}$ inches, closing to $7 \frac{1}{2}$ inches. Orrery Coll.

Both eyepiece and object-glass are fitted with sliding caps. The objective is of 6 inches focus; the four lenses of the erecting eyepiece are mounted in sections of the beautifully made draw-tube which fit together with bayonet joints, engraved for identification with leaves, a ball, and a rose. A small hole is provided to allow the escape of air when the draw-tube is being pushed in.

The invention of the erecting or terrestrial telescope by the application of four lenses is thought to have been made by Compani of Rome.

92. $\mathbf{I}_{8}^{5}$-inch Refractor, of about 9 feet focal length.

c. 1700 .

Orrery Coll. 17 .

Object-glass inscribed Jac: Wilson, Londini fecit, mounted in a wood cell. Pairted wooden tube 3 inches square, with sliding copper cradle with trunnions for use on the tripod belonging to the $1 \frac{1}{4}$-inch refractor described below. Length when closed 6 feet: extension, partly by. a square wooden draw-tube, partly by a round green vellum tube, which serves as a fine adjustment.

The eyepiece is unfortunately imperfect, the two lenses nearest the objective being the only parts remaining of an erecting eyepiece. Writings on the square draw-tube at 8 feet 6 inches, 7 feet 6 inches, and 6 feet from the object-glass describe marks at those points respectively as 'Mark for the longest objective with 3 eyeglasses obiect erected', 'Mark for the shortest objective with 3 ey eglasses obiect erected', and 'Mark for the objective with one eyeglass obiect inverted'. The eye lens and cap are therefore missing. The metal band round the tube at the eyepiece end once carried a hook for suspension. 
This type of instrument was figured in the Phil. Trans. for 1667.

Wilson's microscope lenses were famous, but there cannot be many signed telescope object-glasses now in existence. So far as we know, this one is unique. It is certainly unusual for so long an instrument to be fitted with an erecting eyepiece.

93. $I_{4} \frac{1}{4}$-inch Refractor, of about 7 feet 9 inches focal length.

Orrery Coll. 16.

Lenses mounted in brass mounts at the ends of the 3 -inch square mahogany tube. A sliding cradle with trunnions was used to carry the tube on a tripod stand, but additional steadiness and support was gained by a cord attached to a brass C-hook near the eyepiece end, a support necessitated by the great weight of the heavy micrometer that was used with this instrument.

A wooden bracket bearing two wooden 3 -inch pulley wheels was found among Lord Orrery's apparatus, which may have been employed for supporting his telescopes.

94. Micrometer Eyepiece for ditto.

c. 1700 .

Orrery Coll. 6.

Probably one of the oldest micrometers now in existence.

Gascoigne used a thread micrometer as early as I640, but his method was so little known that even in 17 I 7 Derham considered the facts of Gascoigne's invention worthy of a letter to Crabtree, which was printed in the Philosophical Transactions. This must have been about the date of the Orrery instrument. Gascoigne's micrometer passed into Townley's hands, and he improved it by adding a double threaded screw.

In 1666 Auzont and Picard also devised a thread micrometer, and Romer in 1676 used thirteen silk threads for the same purpose.

\section{Two Square Oak Telescope Tubes.}

Radcliffe Observatory.

A. 8 feet tube, 3 inches square for $2 \frac{1}{4}$ inches obj. Interior octagonal.

B. 2 -draw 7 feet tube, $3^{\frac{1}{2}}$ inches square for $2 \frac{1}{2}$ inches obj. gl. of I3 feet focal length. Also a 5 feet 4 inches extension tube, making a total tube length of 18 feet 6 inches.

96. Telescope Stand.

17-.

Radcliffe Observatory.

Mahogany. 3-draw, triangular section, with brass pivot at top.

97. Mahogany Support for Eyepiece-end of Telescope.

17一.

With altitude screw and azimuth rack.

Radcliffe Observatory. 
Both stands are reminiscent of Hevel's stands (1673) (v. Machina coelestis, pl. x). A similar device is figured in the Hist. Coel., as in use at Greenwich in Flamsteed's time. Cf. fig. in Maunder's R. Obserw. Greenwich.

\section{SURVEYING INSTRUMENTS}

98. Plumb Level and Clinometer.

c. 1579 .

Bodleian Library.

Brass gilt and engraved with Arabesque ornamentation. With pin-hole sights. $9 \frac{1}{2}$ inches wide.

Probably presented by Josias Bodley with the Schissler geometer's Quadrant stated to have come into the Library in $1613 .{ }^{1}$ An oak box fits both instruments.

The plummet (missing) was hung in the centre of an arc of $5 \frac{1}{2}$-inch radius, graduated to $90^{\circ}$ on each side of the normal. The two sights are hinged for packing.

Although this instrument does not appear to have been made by the same hand as the Schissler Quadrate, it was probably used in connexion with it, for the oak Quadrate-case which appears to date from the 17 th century, is recessed for its reception.

Early treatises on surveying are frequently illustrated with excellent pictures showing the method of using quadrants and quadrates. A good example, Bodleian S.C. 2177, of about the year 1275 shows clearly how the height of buildings may be measured.

99. Geometer's Quadrate in gilt brass frame $1_{3} \frac{5}{8}$ inches square. 1579 .

Packed in an oak box which is also fitted to hold a clinometer.

Inscribed on back

Christophorus Schissler Geometricvs ac

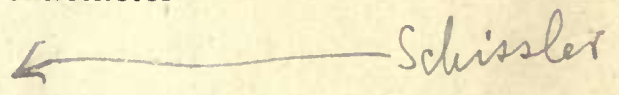

Astronomicvs Artifex

Augustae Vindelicorum faciebat anno domini 1579

Presented by Josias Bodley to the Bodleian Library.

It is said to have come into the Library in $\mathrm{I}_{13}$.

A beautiful example of this master's art. It was formerly regarded as one of the sights of the Library, and was kept in a cupboard in the wooden stand of the Armillary Sphere. Uffenbach saw it on Aug. I9, I7Io, and was told by Crab the sub-librarian that it was made of pure gold.

${ }^{1}$ Bodleian Library copy of Macray's Annals of the Bodleian. 


\section{BACK-STAFF}

100. English or Davis' Quadrant or Back-staff.

Name plate missing.

Pitt-Rivers.

For use cf. Stone's Bion Math. Instr., p. 204.

101. English or Davis' Quadrant or Back-staff.

Edm : Culpepper fecit.

Pear-tree wood. Decorated with rose and fleur de lys stamps.

OCTANTS AND SEXTANTS

102. 18-inch Octant, with ivory scale and dark glasses and pin-hole sights.

17-.

Oriel College.

103. 10-inch Octant, ditto.

17-.

Pitt-Rivers.

104. 16-inch Octant, ditto. With a pendent brass label marked E.

Gunther Collection.

105. 6.inch Sextant with pin-hole sights.

17一.

By Jos. Jackson, London, No. x22.

Oriel College

106. 6 -inch Sextant with telescope in mahogany case.

I7一.

By J. Dollond and Son, London.

Oriel College.

107. Circumferentor or Surveying Compass. Brass.

c. 1690.

I: Worgan fecit.

Orrery Coll. 15 .

The base plate in a circle 13 inches in diameter, with a border divided into $\frac{1}{2}$ degrees; two slit and thread sights are carried at the $0^{\circ}$ and $180^{\circ}$ marks.

108. Graphometer or Surveying Semicircle.

With folding tripod stand $4^{\frac{1}{2}}$ feet in height. 109. Plane Table.

c. 1690 . Orrery Coll. $5^{\circ}$.

Orrery Coll. 18. 1696.

$13^{\frac{1}{2}} \times 10^{\frac{1}{2}}$ inches with Compass in a wooden bracket at one side.

110. Large Burning Glass.

\section{LENSES}

Chemical Department.

There is nothing to show who was the maker of this large lens, but it undoubtedly dates from the days of the old Ashmolean Laboratory. 
Such burning glasses - 12 and 16 inches in diameter-were used by Joseph Priestley, c. I770, who obtained them from Samuel Parker (d. I8I 7), a London optician.

111. Portable Camera Obscura. c. 1700. 9 inches $\times 3 \frac{1}{2}$ inches. Orrery Coll. $3^{8 .}$

112. Sky Optick, with convex lens in Lignum vitae ball. c. I750-180o. ? cf. Gehler, Phys. Wörterbuch, v, Leipzig, I795, p. 82. Oriel College.

\section{MICROSCOPES}

113. Wilson's Pocket or Screw Barrel Microscope.

By Wilson. Ivory body.

1702.

Orrery Coll. 26.

Complete with lenses, object forceps, \&c., in shagreen case (Phil. Trans., No. 281).

114. Small Screw Barrel Microscope.

By (or after) Wilson.

Later than $\mathbf{1 7 0 2 .}$

Clarendon Laboratory.

115. Double Microscope for viewing the Circulation of the Blood.

By John Marshall.

1693 .

No. 8, Orrery Coll. Ch. Ch.

This microscope is of the very greatest importance from the standpoint of the history of the instrument, on account of the extreme rarity of models of this period; and the historic value of this particular instrument is all the greater because it has been shut up in a cupboard with the rest of the Orrery apparatus since 1720 . It is therefore likely to be in its original state.

116. Microscope with Wooden Body and Tripod.

? 1750. Pitt-Rivers Coll.

A modification of the Culpeper and Scarlet model of 1738 .

117. Culpeper's Microscope.

Ivory body on brass pillar stand.

Pitt-Rivers Coll.

Marked E. Culpeper, Londini.

The folding feet of the stand are engraved :-

Microscopes Telescopes \& all sorts of Optick Glasses Improv'd and made to $y^{e}$ greatest perfection by EDM: CULPEPER co MATHEMATICAL Instruments of all sorts in Gold Silver Brass Ivory \& Wood accurately divided \& made to ye greatest perfection.

Spectacles Reading Glasses in great Variety of Convex and Concave Glasses also Load Stones. Set in Gold and Silver \&c. 
118. Cuff's Double Constructed Microscope and Stand. ? 176r. In pyramidal mahogany case.

(By) Dollond, London.

Christ Church.

Inscription :-

D.D. Joannes Tunnadine LL.D (? I 768-71).

(With MS. Catalogue of 6 ivory slides, each with four objects.)

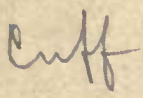

119. Cuff's Double Constructed Microscope and Stand with Oblique Mirror for Solar Illumination.

I746-71.

Christ Church.

(By) G. Adams at No. 6o Fleet Street, London.

120. Cuff's Model Microscope.

17-.

Nairne London Invt. et Fecit.

Oriel College.

121. Compound Microscope on Tripod Stand.

By Jupp. With Cuff stage.

Clarendon Laboratory.

\section{ADDENDA}

53a. Persian Astrolabe.

The earliest dated Astrolabe known.

A. $\mathbf{H} \cdot 374=$ A. D. 984 .

Brass : diameter $5 \frac{1}{4}$ inches, thickness $\frac{1}{8}$ inch.

The inscription means:

'In the Name of God, and by the help of God,

In prosperity, and wealth and good fortune, and the happiness of this world and the next and eternity.'

This is the Astrolabe of Ahmad and Mahmūd, the sons of Ibrahim, the Astrolabist of Isfahan. It is made for thirty-seven stars, contains three plates, and has the latitudes and longitudes of thirty-two cities engraved in the mother.

53 b. Moorish Astrolabe.

Brass : diameter $6 \frac{5}{8}$ inches, thickness $\frac{1}{4}$ inch.

A. $H .460=$ A. D. 1067 .

The inscription is:

'Made by Ibrahim Ibn Said Assohli, in the city of Toledo, in Shoulal, of the year 460 .'

- It is made for twenty-eight stars, and contains six plates. 



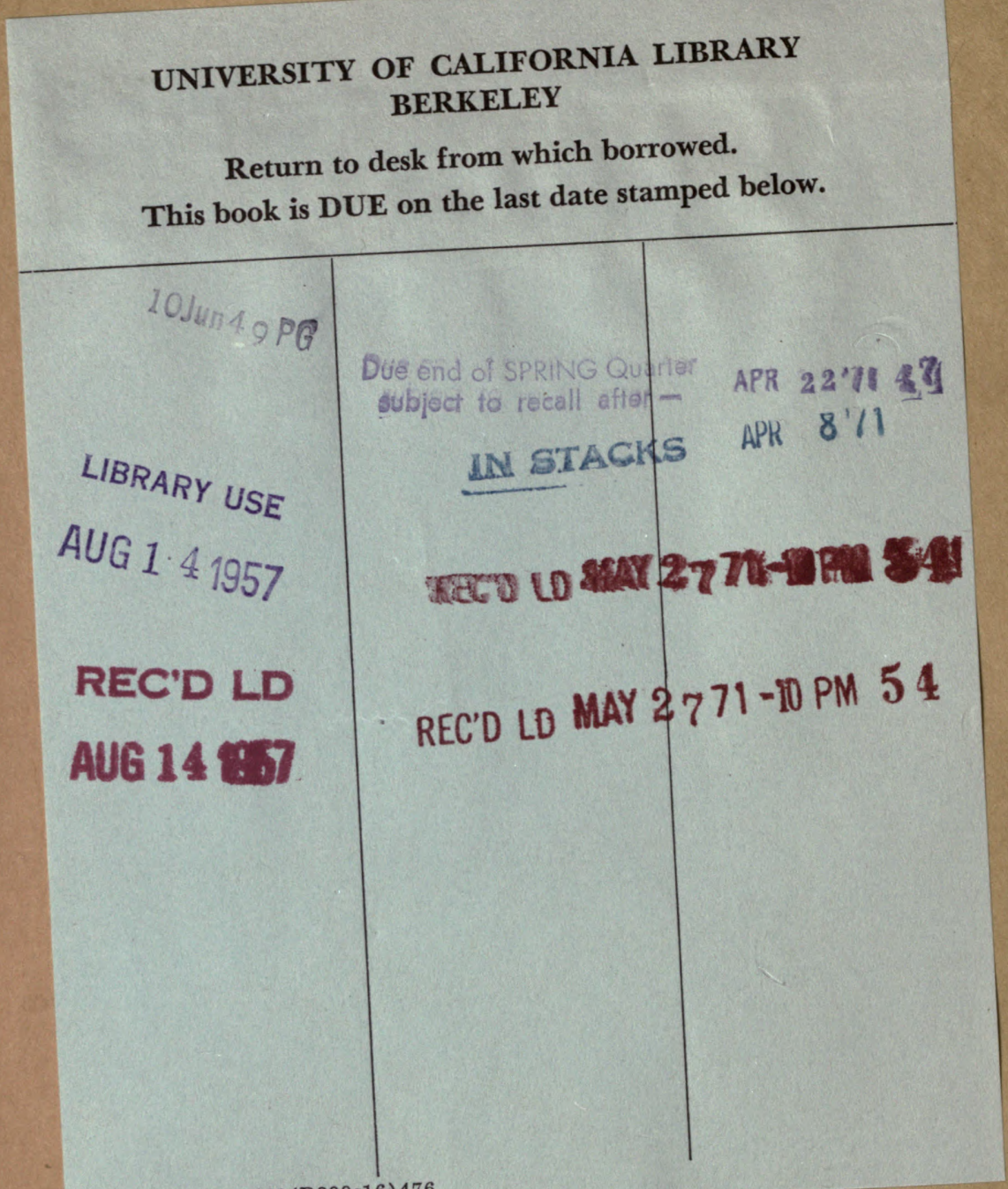


Oxford. University

Binder

Gaylord Bros., Inc. Makers

Stockton, Calif.

PAI. JAN. 21, 1908

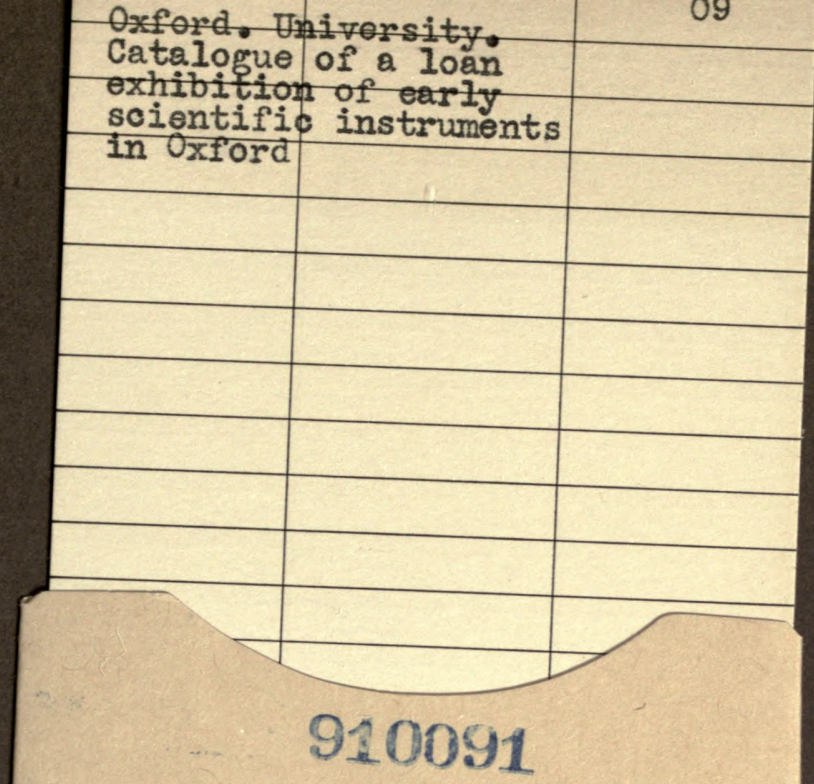

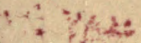

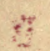

Q 185

09

4

,

THE UNIVERSITY OF CALIFORNIA LIBRARY 
